\title{
Cytotoxic Activities of Acetogenins from Annona dioica Roots
}

\author{
Marina M. Paesa,b, Maria R. G. Vegaa, Diego Cortesc, Nuria \\ Cabedoc, Milton M. Kanashirob
}

\begin{abstract}
áLaboratório de Ciências Química, Centro de Ciência e Tecnologia, Universidade Estadual do Norte Fluminense Darcy Ribeiro, 28013-612 Campos dos Goytacazes - RJ, Brazil.

bLaboratório de Biociências e Biotecnologia, Centro de Ciência e Tecnologia, Universidade Estadual do Norte Fluminense Darcy Ribeiro, 28013-612 Campos dos Goytacazes - RJ, Brazil.

${ }^{c}$ Departamento de Farmacología, Facultad de Farmacia, Universitat deValència, , 46100 Burjassot, Valencia -Spain.
\end{abstract}

\begin{abstract}
Phytochemical investigation of the chloroformic extract of the roots of Annona dioica (Annonaceae) led to the first time to the isolation of acetogenins in this plant. Their structure were identified as known motrilin (1), squamocin (2), cherimolin-1 (3), isocherimolin-1 (4), annonacin (5) and isoannonacin (6) on the basis of spectroscopic (NMR) and spectrometric (MS) analyses. All the compounds were evaluated against human tumor cell and human non-tumor cells. The Annonaceous acetogenins 2, 3 and $\mathbf{5}$ showed significant in vitro cytotoxicity toward U-937 (histiocytic lymphoma).
\end{abstract}

Keywords: Annona dioica, Annonaceous acetogenins, cytotoxic activity

\section{Introduction}

Since the 1980`s Annonaceous plants have come under intense scrutiny as potencial sources of the potential biologically active Annonaceous acetogenins (ACGs). ${ }^{1}$ This secondary metabolites derived from the polyketide pathway possess a strong antitumor activity. Therefore, ACGs may be judged as promising candidates for a future generation of drugs to fight against the current chemotherapy-resistant tumors. ${ }^{2}$

The Annonaceous acetogenins are a large group of natural products isolated from a few number of genus of the Annonaceae family (Annona, Asimina, Goniothalamus, Rollinia, Xylopia, Uvaria and more recently from Polyalthia, Porcelia and Disepalum). ${ }^{3}$ In over 35 years, more than 500 acetogenins were isolated from various plant parts of this family. ${ }^{4}$

Annona dioica St. Hill belongs to the family Annonaceae and have been reported to traditional medicinal use. ${ }^{5}$ In Brazil, their fruits and leaves are used against rheumatism and their seeds against diarrhea. To date, the previous phytochemical investigation of this plant has proved that it contains compounds like flavonoids and alkaloids. These flavonoids exhibited significant antiproliferative action against Ehrlich carcinoma cells. ${ }^{6-8}$ Focusing on the searching for bioactive ACGs as secondary metabolites from the Annona genus, we describes for the first time the isolation of acetogenins from $A$. dioica strengthens chemical data and its chemosystematic position. This paper reports six known ACGs motrilin (1), squamocin (2), cherimolin1 (3), isocherimolin-1 (4), annonacin (5) and isoannonacin (6) (Figure 1). The structures of the known compounds were confirmed by comparison of their spectrometry and spectroscopic data (MS, ${ }^{1} \mathrm{H}$ and ${ }^{13} \mathrm{C}$ NMR) with literature references. In addition, these acetogenins (1-6) were evaluated for cytotoxic activities against human tumor cell U-937 (histiocytic lymphoma), THP-1 (acute monocytic leukemia), NCIH460 (large cell lung cancer) and COLO 205 (colorectal adenocarcinoma) cell lines and human nontumor cells (PBMCs).

This article is published under the terms of the Creative Commons Attribution License 4.0 Author(s) retain the copyright of this article. Publication rights with Alkhaer Publications.

Published at: http://www.ijsciences.com/pub/issue/2015-12/

DOI: 10.18483/ijSci.875; Online ISSN: 2305-3925; Print ISSN: 2410-4477 
<smiles>CC=CC=CCC(O)CCCC[C@@H](O)[C@@H]1CC[C@H]([C@H]2CC[C@H]([C@@H](O)CCCCCCC3=CC(C)OC3=O)O2)O1</smiles>

Motrilin (1)<smiles>CCCCCCC(O)CCC[C@@H](O)[C@H]1CC[C@H]([C@H]2CC[C@H]([C@H](O)CCC[CH]CCC3=CC(C)OC3=O)O2)O1</smiles>

Squamocin (2)<smiles>CCCCC[C@@H](O)[C@H]1CC[C@@H]([C@@H](O)CC[C@H](O)[C@H]2CCC(CCCCCCCC(O)CC3=CC(C)OC3=O)O2)O1</smiles>

Cherimolin-1 (3)<smiles>CCCC[C@@H](O)[C@H]1CC[C@@H]([C@H](O)CC[C@H](O)[C@H]2CCC(CCCCCCCC3CC(CC(C)=O)C(=O)O3)O2)O1</smiles>

Isocherimolin-1 (4)<smiles>CCCCCC[C@H](O)[C@H]1CC[C@@H]([C@@H](O)CCCCC(O)CCCCCC(O)CC2=CC(C)OC2=O)O1</smiles>

Annonacin (5)<smiles>CCCCCC[C@H](O)[C@H]1CC[C@@H]([C@H](O)CCCCC(O)CCCCCC2CC(CC(C)=O)C(=O)O2)O1</smiles>

Isoannonacin (6)

Figure 1. Acetogenins isolated from Annona dioica roots.

\section{Experimental}

Plant material

The roots of A. dioica were collected in April 2003 at Cerrado of Horqueta, Paraguay. A voucher specimen (No. 8567) has been deposited in the Departamento de Botanica of Universidad Nacional, Asunción, Paraguay.

Extraction and Isolation

The roots of A. dioica were powdered and macerated at room temperature with $\mathrm{MeOH} / \mathrm{H}_{2} \mathrm{O}(90: 10 \mathrm{v} / \mathrm{v})$. The solvent was removed under pressure, obtaining the crude extract (120.2 g). This extract was partitioned between $\mathrm{CHCl}_{3}, \mathrm{EtOAc}$ and $\mathrm{MeOH}$ to obtain the following extracts: $\mathrm{CHCl}_{3}(6.02 \mathrm{~g})$, EtOAc $(0.82 \mathrm{~g})$ and $\mathrm{MeOH}(1.44 \mathrm{~g})$. The TLC analysis indicated a high concentration of acetogenins in the $\mathrm{CHCl}_{3}$ extract. Therefore, the $\mathrm{CHCl}_{3}$ was fractionated by column chromatography $(\mathrm{CC})$ on silica gel flash. The column was eluted with $\mathrm{CHCl}_{3}: \mathrm{MeOH}$ with increasing polarity to give 10 fractions (1-10). Fraction 2 was purified by 
silica gel flash $\mathrm{CC}$ eluted with hexane/ $\mathrm{CHCl}_{3} /$ isopropyl alcohol $(25: 25: 4 \mathrm{v} / \mathrm{v} / \mathrm{v})$ to furnish 1 (30.0 mg). Separation of fraction 3 by silica gel flash $\mathrm{CC}$ eluted with hexane/ $\mathrm{CHCl}_{3} /$ isopropyl alcohol (24:20:4 v/v/v), yielded subfractions 3.1-3.5. Fraction 3.2 was subjected to silica gel flash CC eluted with hexane/ $\mathrm{CHCl}_{3} /$ isopropyl alcohol $(20: 30: 4 \mathrm{v} / \mathrm{v} / \mathrm{v})$ to give $2(22.1 \mathrm{mg})$. Fraction 5, after sucessive silica gel flash $\mathrm{CC}$ using hexane/EtOAc/MeOH as eluent, allowed to isolation of compounds $\mathbf{3}(25.4 \mathrm{mg})$ and $\mathbf{4}$ $(9.0 \mathrm{mg})$. Fraction 7 was purified by silica gel flash CC eluted with hexane/ EtOAc/MeOH (35:35:4 v/v/v), yielding subfractions 7.1-7.6. Subfraction 7.3 was submitted to silica gel flash CC eluted with hexane/ $\mathrm{CHCl}_{3}$ /isopropyl alcohol $(24: 30: 4 \mathrm{v} / \mathrm{v} / \mathrm{v})$ to afford $6(10.0 \mathrm{mg})$. Fraction 8 wich was purified by silica gel flash $\mathrm{CC}$ eluted with hexane/ $\mathrm{CHCl}_{3} / \mathrm{MeOH}$ $(32: 22: 4 \mathrm{v} / \mathrm{v} / \mathrm{v})$ gave compound $5(20.5 \mathrm{mg})$.

\section{NMR data}

${ }^{1} \mathrm{H}$ and ${ }^{13} \mathrm{C}$ spectra were obtained on a BRUKER model DPX-500 spectrometer operating at $300 \mathrm{MHz}$ for ${ }^{1} \mathrm{H}$ and $500 \mathrm{MHz}$ for ${ }^{13} \mathrm{C}$, in $\mathrm{CDCl}_{3}$, using TMS as internal standard.

Cell lines and Cytotoxic assays

U-937 (histiocytic lymphoma), THP-1 (acute monocytic leukemia), NCI-H460 (large cell lung cancer) and COLO 205 (colorectal adenocarcinoma) cell lines were provided by the American Type Culture Collection (ATCC). The human non-tumor cell PBMC (peripheral blood mononuclear cells) were obtained from health donors in Sodium Heparin glass tubes "VacutainerTM" (Becton Dikinson) and isolated over Ficoll-Paque $^{\mathrm{TM}}$ Plus $\left(1,08 \mathrm{~g} \mathrm{~mL}^{-1}\right)(2: 1$ - blood:ficoll $)$, as described by Bennett \& Breit. ${ }^{9}$ The cells were cultured with DMEM/F-12 (Gibco) medium containing $10 \%$ fetal bovine serum (Gibco) and gentamicin $20 \mu \mathrm{g} \mathrm{mL}^{-1}$ (Gibco). The culture was maintained at $37{ }^{\circ} \mathrm{C}$ in a humidified atmosphere containing $5 \% \mathrm{CO}_{2}$. Bryefly, cells were incubated in 96-well plates $\left(1 \times 10^{6}\right.$ cells/well) containing $100 \mu \mathrm{L}$ of the culture medium and treated with various concentrations of the compounds (1-6) during $48 \mathrm{~h}$.

The cytotoxicity of acetogenins was analyzed by colorimetric 3-[4,5-dimethylthiazol- 2-yl-]2,5diphenyl tetrazolium bromide (MTT) assay, as described previously by Mosmann. ${ }^{10}$ At time of $48 \mathrm{~h}$ after addition of the compounds 1-6, $20 \mu \mathrm{L}$ of MTT (5mg $\mathrm{mL}^{-1}$-Sigma) was added to each well and then the plates were incubated for another $4 \mathrm{~h}$ at $37{ }^{\circ} \mathrm{C}$. After incubation for $4 \mathrm{~h}$, the medium was removed, and then the formazan was dissolved in dimethyl sulfoxide (DMSO) (Sigma). Finally, optical density (OD) monitored at $570 \mathrm{~nm}$ using a Microplate Reader (Multiskan-EX). Cytotoxicity of each sample is expressed as $\mathrm{IC}_{50}$ value (the concentration that inhibits growth in $50 \%$ ) and were determined using the computer software GraphPad Prism 5.0. One-way ANOVA was used for the comparison of means $(p<$ $0.05)$. Each experiment was repeated three times. Doxorubicin was used as positive control.

\section{Results and Discussion}

The fractionation of the chloroformic extract of the roots of $A$. dioica collected in Paraguay leading to isolation of six acetogenins identified by comparison of their spectroscopic data with those reported in the literature. These belong to three different types: (a) adjacent bis-tetrahydrofuran (THF) acetogenins, motrilin (1) and squamocin (2); ${ }^{11,12}$ (b) nonadjacent bis-tetrahydrofuran (THF) acetogenins, cherimolin-1 (3) and isocherimolin-1 (4); ${ }^{13,14}$ and (c) monotetrahydrofuran (THF) acetogenins annonacin (5) and isoannonacin (6) (Figure 1). ${ }^{15,16}$ The structural identification of these ACGs was based on their ${ }^{1} \mathrm{H}$ and ${ }^{13} \mathrm{C}$ NMR spectral data, including the homonuclear 2D $\mathrm{H}-\mathrm{H}-\mathrm{COSY}$ and heteronuclear 2D ${ }^{1} \mathrm{H}-{ }^{13} \mathrm{C}$ shiftcorrelated (HMQC and HMBC). Compounds 1-6 are the first acetogenins isolated in this specie.

The cytotoxicities of six ACGs and standard control doxorrubicin against the growth of four human tumor cells (U-937, THP-1, NCI-H460 and COLO 205) and a human non-tumor cells (PBMC) were assayed using MTT method. ${ }^{10}$ The $\mathrm{IC}_{50}$ values are shown in Table 1.

Archievements in the studies of ACGs are noted by their significant cytotoxicity. In several papers, the ACGs consistently showed selective cytotoxicities as $\mathrm{IC}_{50}$ values ranging from $10^{-1}$ to $10^{-12} \mu \mathrm{g} \mathrm{mL}^{-1}$ in the larger panel of human tumor cell lines. ${ }^{3,17-19}$ So, in the present study, we hope to be able to have structureactivity relationships (SARs) data of six diverse ACGs and find a new selective cytotoxic agent for certain cancer types that provide a good selective index (SI).

Table 1. Cytotoxic activity expressed by $\mathrm{IC}_{50}\left(\mu \mathrm{g} \mathrm{mL} \mathrm{L}^{-1}\right)$ of acetogenins against tumor human cell lines and non-tumor human cells.

\begin{tabular}{cccccc}
\hline \multirow{2}{*}{ Compounds } & \multicolumn{5}{c}{ Cytotoxic activity $\mathrm{IC}_{50}\left(\mu \mathrm{g} \mathrm{mL} \mathrm{mL}^{-1}\right)$} \\
\cline { 2 - 6 } & $\mathrm{U}-937$ & $\mathrm{THP}-1$ & $\mathrm{NCI}-\mathrm{H} 460$ & $\mathrm{COLO} \mathrm{205}$ & PBMC \\
\hline $\mathbf{1}$ & $13.1 \pm 1.1$ & $9.4 \pm 1.0$ & $37.3 \pm 1.2$ & $>100$ & $>100$ \\
$\mathbf{2}$ & $3.9 \pm 1.1$ & $5.2 \pm 1.1$ & $12.8 \pm 1.0$ & $9.7 \pm 1.0$ & $26.2 \pm 1.0$
\end{tabular}




\begin{tabular}{cccccc}
$\mathbf{3}$ & $3.8 \pm 1.1$ & $6.4 \pm 1.1$ & $9.5 \pm 1.1$ & $23.8 \pm 1.1$ & $42.5 \pm 1.1$ \\
$\mathbf{4}$ & $7.3 \pm 1.1$ & $5.8 \pm 1.1$ & $35.8 \pm 1.1$ & $>100$ & $43.8 \pm 1.1$ \\
$\mathbf{5}$ & $3.5 \pm 1.1$ & $3.7 \pm 1.1$ & $11.9 \pm 1.1$ & $15.6 \pm 1.1$ & $29.5 \pm 1.0$ \\
$\mathbf{6}$ & $6.2 \pm 1.1$ & $5.4 \pm 1.1$ & $10.8 \pm 1.1$ & $32.2 \pm 1.1$ & $39.9 \pm 1.0$ \\
Doxorrubicin $^{\mathrm{a}}$ & $2.2 \pm 1.0$ & $1.9 \pm 1.1$ & $>100$ & $>100$ & $26.9 \pm 1.2$ \\
\hline
\end{tabular}

aPositive control

As shown in the Table 1, all diverse ACGs exhibited diferent potent cytotoxicity against the growth of diferent human tumor cell lines. Activity seen at a concentration less than $4-5 \mu \mathrm{g} \mathrm{mL}^{-1}$ has been chosen for designating a substance as "cytotoxic". ${ }^{20}$ The cytotoxic effects of adjacent bis-THF actogenins $\mathbf{1}$ and $\mathbf{2}$, revelead that $\mathbf{2}$ was more cytotoxic against U-937, THP-1, NCI-H460 and COLO 205, compared with 1. The only difference between $\mathbf{1}$ and $\mathbf{2}$ concerns the hydroxyl group position, $\mathbf{1}$ with a hydroxyl group at C29 while 2 with a hydroxyl group at C-28. It was noted that the position of hydroxyl group failed to significantly affect the activities. Comparing the activity of nonadjacent bis-THF acetogenins 3 and its iso-type 4, compound 3 showed more selective against U-937, NCI-H460 and COLO 205. The regularity could be further supported by comparing the activity of mono-THF acetogenins 5 and its iso-type $\mathbf{6}$. Compound 5 showed more selective against U-937, THP-1 and COLO 205. This study showed that the isoacetogenins 4 and $\mathbf{6}$, derived from the corresponding 4-hydroxyacetogenins by translactonization, showed a less inhibitory potency comparing the activity of a non-isoacetogenin corresponding $\mathbf{3}$ and $\mathbf{5}$, respectively, for the U-937, THP-1, NCI-H460 and COLO 205 cells. The only exception is 6 for the NCI-H460 and 4 for the THP-1.

In fact, the data show the extremely cytotoxicity of adjacent bis-THF $2\left(\mathrm{IC}_{50}=3.9 \pm 1.1 \mu \mathrm{g} \mathrm{mL}^{-1}\right)$, nonadjacent bis-THF $3\left(\mathrm{IC}_{50}=3.8 \pm 1.1 \mu \mathrm{g} \mathrm{mL}-1\right)$, and mono-THF $5\left(\mathrm{IC}_{50}=3.5 \pm 1.1 \mu \mathrm{g} \mathrm{mL}^{-1}\right)$ against $\mathrm{U}-937$ cells, and $5\left(\mathrm{IC}_{50}=3.7 \pm 1.1 \mu \mathrm{g} \mathrm{mL}^{-1}\right)$ against THP-1 cells, with $\mathrm{IC}_{50}<4 \mu \mathrm{g} \mathrm{mL}$. In constrast, these compounds and 1, 4, and $\mathbf{6}$ are not effective agents in NCI-H460 and COLO 205 cells, with IC $_{50}$ values ranging from 9 to $>100 \mu \mathrm{g} \mathrm{mL}^{-1}$. So, regarding the NCI-H460 and COLO 205 cells lines, the 1-6 ACGs did not exhibit selective cytotoxicity.

Generally, the SARs studies showed the most potent groups of Annonaceous acetogenins are adjacent bisTHF acetogenins, followed by the non-adjacent bisTHF acetogenins. Mono-THF acetogenins show an intermediate potency. However, some reviews of these data reveals different general tendencies for each tumor cell line..$^{2,3,19}$ Interestingly, against U-937 cells the three types of structures across the THF ring offer a convenient activity, but against THP-1 cells only mono-THF ACG $\mathbf{5}$ was considered as highly cytotoxic. Thus, in general our results shown that mono-THF acetogenin $\mathbf{5}$ was the most potent compound.

Therefore, data from these assays are often puzzling because the analysis of these results does not clarify a comum SARs of the Annonaceous acetogenins. Altered biological transport or slight variations in receptor geometry in the membranes of such cell lines might explain these selectivities. This observation serves to demonstrate the necessity and merit of a search for new structural themes. ${ }^{3,19}$

More research should be carried out, especially the use of normal cell lines to clarify the selectivity of the cytotoxic effect against cancer cell lines to prove that the compounds can be used safely. ${ }^{21}$ Furthermore, in assessing the anticancer potential of a pure compound, the $\mathrm{SI}$ ( $\mathrm{SI}=\mathrm{IC}_{50}$ non-tumor cells/ $/ \mathrm{IC}_{50}$ tumor cells) is essential. $^{22}$ Unfortunately, a significant number of authors do not take that into consideration. Thus, it is very hard to draw any conclusions on the future potencial of these compounds as anticancer drugs because no data on their selectivity are provided. ${ }^{23}$ So, from the point of view of the biological activity of ACGs we estimate the potential of this compounds determining the cytotoxicity against non-tumor human cells (PBMC) and the SI, describing for the first time the ratio of $\mathrm{IC}_{50}$ human non-tumor cells to the cancer cells (SI) for 1-6 ACGs (Tab. 2).

As the SI demonstrates the differential activity of a pure compound, when the SI value is greater, it is more selective. An SI value less than 2 indicates general toxicity of the pure compound. ${ }^{24}$ Based on this, the SI data showed in Table 2 indicate that the potent compounds squamocin (2), cherimolin-1 (3) and annonacin (5) against U-937 cells and the compound 5 against THP- 1 cells with $\mathrm{IC}_{50}<4 \mu \mathrm{g} \mathrm{mL}^{-1}$, exhibit a high degree of cytotoxic selectivity, with SI values $>$ 2 , an exceptional high selectivity in terms of acetogenins activity. Compound 3 for U-937 cells shows SI $=11.74$. This activity is not so different than that of the reference drug, doxorrubicin $(\mathrm{SI}=11.96$, U-937). This suggests that the compounds $\mathbf{2}, \mathbf{3}$ and $\mathbf{5}$ are the most promising. 
Table 2. Selective index.

Selective index (SI)

\begin{tabular}{crccc}
\cline { 2 - 4 } Compounds & U-937 & THP-1 & NCI-H460 & COLO 205 \\
\hline $\mathbf{1}$ & $>7.0$ & $>7.0$ & $>2.0$ & - \\
$\mathbf{2}$ & 6.60 & 5 & 2.04 & 2.69 \\
$\mathbf{3}$ & 11.74 & 6.62 & 4.48 & 1.78 \\
$\mathbf{4}$ & 5.97 & 7.55 & 1.22 & $<1.0$ \\
$\mathbf{5}$ & 8.26 & 7.97 & 2.46 & 1.89 \\
$\mathbf{6}$ & 6.37 & 7.31 & 3.68 & 1.23 \\
Doxorrubicin $^{\mathrm{a}}$ & 11.96 & 13.73 & $<1.0$ & $<1.0$ \\
\hline
\end{tabular}

${ }^{\text {aPositive control }}$

\section{Conclusions}

In conclusion, the chemical investigation of the roots of $A$. dioica resulted for the first time in the isolation of acetogenins. All the six acetogenins was evaluated against human tumor cells lines and human non-tumor cell and our results suggests the compounds squamocin (2), cherimolin-1 (3) and annonacin (5) are the most promising, being high specific agents against U-937 cells.

\section{Supplementary Information}

Supplementary data are available free of charge at http://jbcs.sbq.org.br.

\section{Acknowledgements}

The authors thank the governamental Brazilian agencies CNPq, CAPES and FAPERJ. Marina M. Paes was the recipient of a fellowship from CAPES-Proc. $\mathrm{n}^{\mathrm{o}}$

\section{BEX8907/14-5.}

\section{References}

1. Rupprecht, J. K.; Hui, Y. H.; McLaughlin, J. L.; J. Nat. Prod. 1990, 53, 237.

2. Bermejo, A.; Figadère, B.; Zafra-Polo, M. C.; Barrachina I.; Estornell, E.; Cortes, D.; Nat. Prod. Rep.2005, 22, 269.

3. Tormo, J. R.; Gallardo, T.; González, M. C.; Bermejo, A.; Cabedo, N.; Andreu, I.; Estornell, E.; Curr. Top. Phytochem. 1999, 2, 69.

4. Liaw, C. C; Wu, T. Y.; Chang, F. R.; Wu, Y. C.; Planta Med. 2010, 76, 1390.

5. Pott, A; Pott, V. J.; In Plantas do Pantanal. Centro de Pesquisa Agropecuária do Pantanal (CPAP), Brasília,
Brazil, 1994.

6. Santos, P. R. D.; Morais, A. A.; Braz-Filho, R.; J. Braz Chem. Soc. 2003, 14, 396

7. Vega, M. R. G.; Esteves-Souza, A.; Vieira, I. J. C; Mathias, L.; Braz-Filho, R.; Echevarria, A.; J. Braz. Chem. Soc. 2007, 18, 1554

8. Formagio, A. S.; Kassuaya, C. A.; Neto, F. F.; Volobuff, C.R.; Iriguchi, E. K.; Vieira, M. C.; Foglio, M. A.; BMC Complement. Altern. Med. 2013, 13, 1 .

9. Bennett, S.; Breit, S.N.; J. Leukoc. Biol. 1994, 56, 236

10. Mosmann, T. J.; Immunol. Methods. 1983, 65, 55.

11. Cortes, D.; Myint, S. H.; Hocquemiller, R.; Tetrahedron. 1991, 47, 8195 .

12. Fujimoto, Y.; Eguchi, T.; Kakinuma, K.; Ikekawa, N.; Sahai, M.; Gupta, Y. K.; Chem. Pharm. Bull. 1988, 36, 4802 .

13. Cortes, D.; Myint, S. H.; Dupont, B.; Davoust, D.; Phytochemistry. 1993, 32, 1475.

14. Hui, Y. H.; Rupprechet, J. K.; Anderson, J. E.; Wood, K V.; McLaughlin, J. L.; Phytother. Res. 1991, 8, 124

15. McCloud, T. G.; Smith, D. L.; Chang, C. J.; Cassady, J. M.; Experientia. 1987, 43, 947.

16. Xu, L.; Chang, C.; Yu, J. G.; Cassady, J. M.; J. Org. Chem. 1989, 54, 5418 .

17. Rupprecht, J. K.; Hui, Y. H.; McLaughlin, J. L.; J. Nat. Prod. 1990, 53, 237.

18. Fang, X. P.; Rieser, M. J.; Gu, Z. M.; McLaughlin, J. L.; Phytochem. Anal. 1993, 4, 27.

19. Zeng, L.; Ye, Q.; Oberlies, N. H.; Shi, G.; Gu, Z. M.; He, K.; McLaughlin, J. L.; Nat. Prod. Rep. 1996, 13, 275.

20. Suffness, M.; Douros, J.; J. Nat. Prod. 1982, 45, 1.

21. Smejkal, K.; Phytochem. Rev. 2014, 13, 245.

22. Seca, A. M.; Grigore, A.; Pinto, D. C.; Silva, A. M.; J. Ethnopharmacol. 2014, 154, 286.

23. Podolak, I.; Galanty, A.; Sobolewska, D.; Phytochem. Rev. 2010, 9, 425.

24. Koch, A.; Tamez, P.; Pezzuto, J.; Soejarto, D.; J. Ethnopharmacol. 2005, 101, 95. 


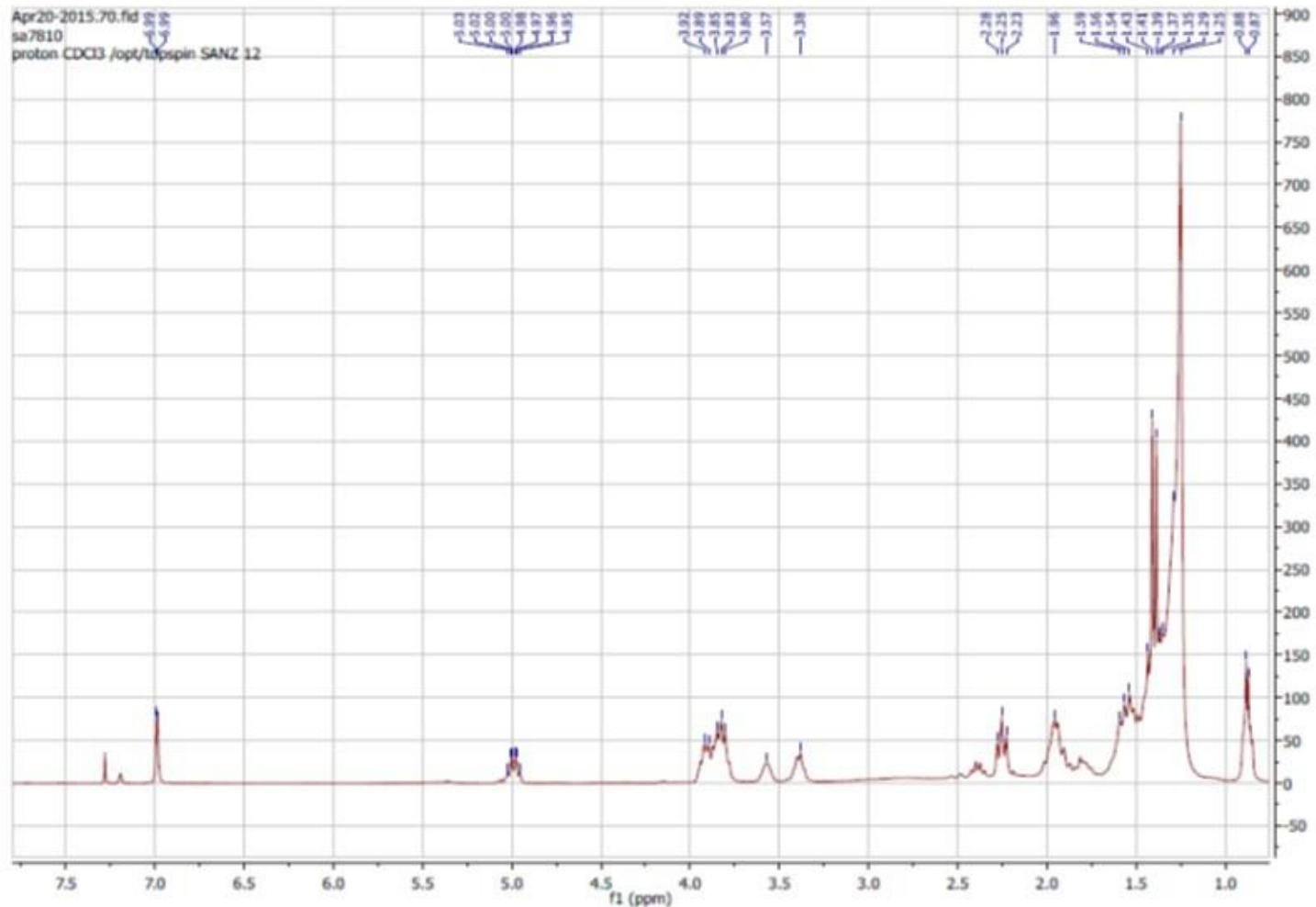

Figure S1. ${ }^{1} \mathrm{H}$ NMR spectrum $\left(300 \mathrm{MHz}, \mathrm{CDCl}_{3}\right)$ of compound 1 .

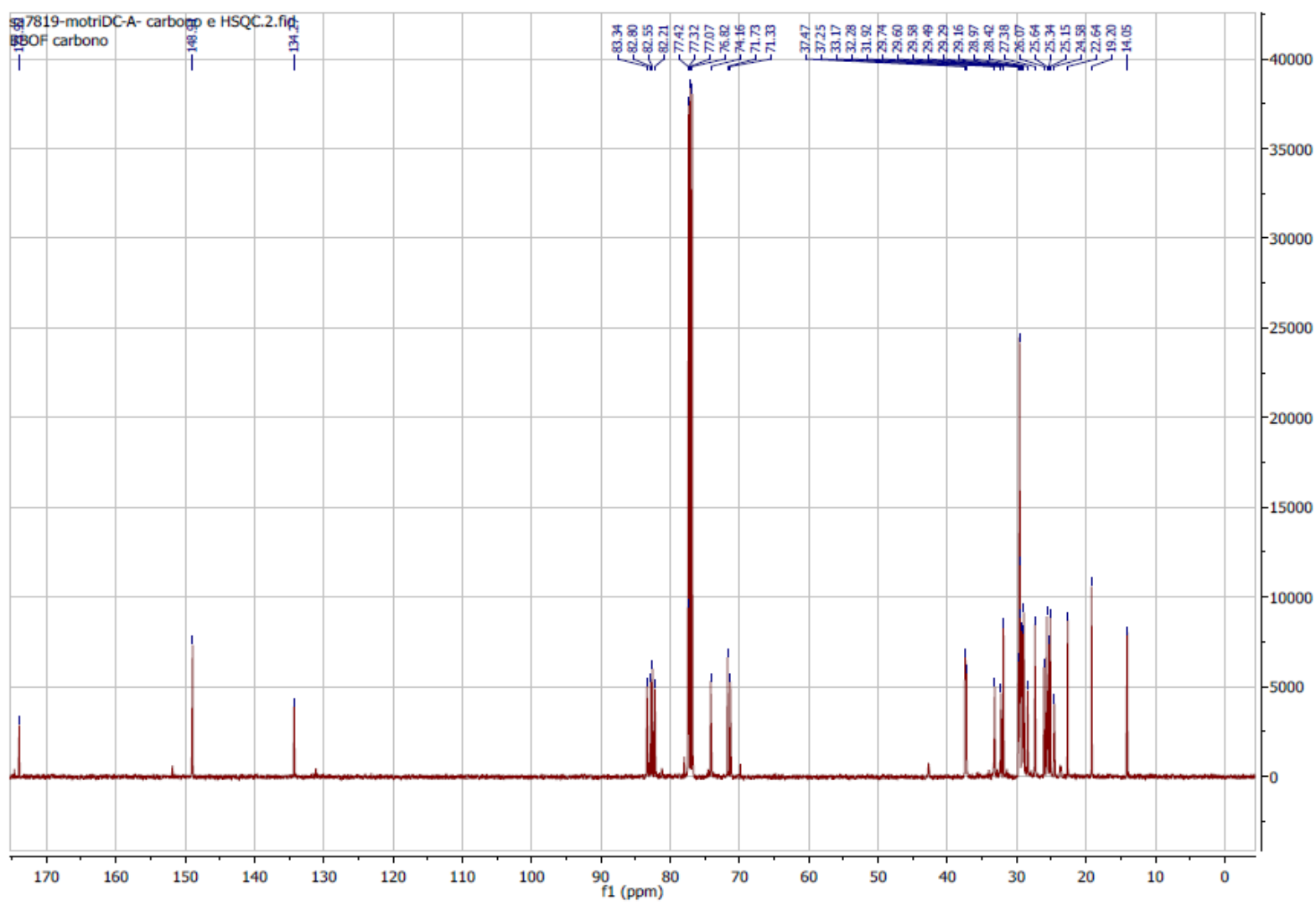

Figure S2. ${ }^{13} \mathrm{C}$ NMR spectrum $\left(500 \mathrm{MHz}, \mathrm{CDCl}_{3}\right)$ of compound $\mathbf{1}$. 


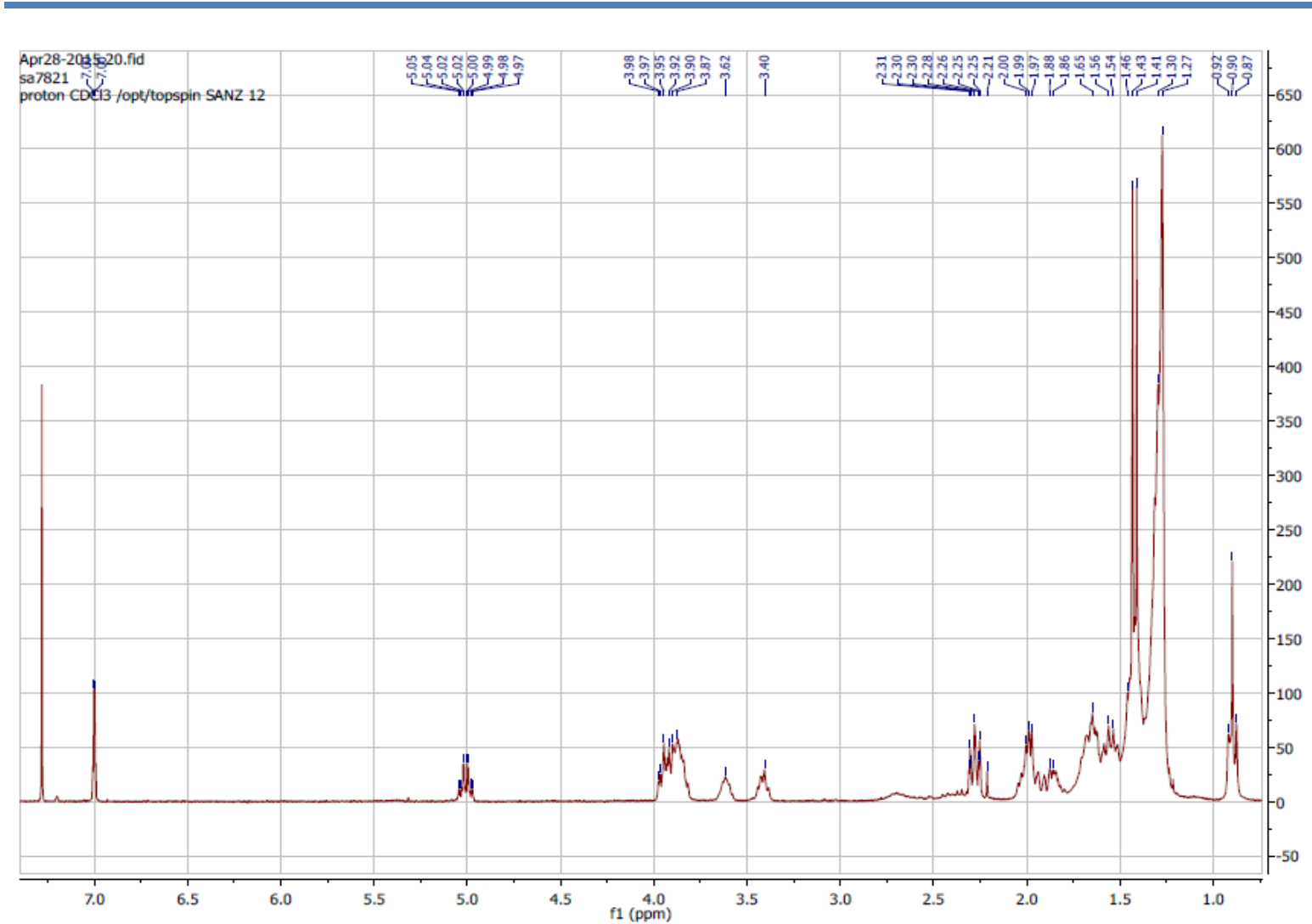

Figure S3. ${ }^{1} \mathrm{H}$ NMR spectrum $\left(300 \mathrm{MHz}, \mathrm{CDCl}_{3}\right)$ of compound 2.

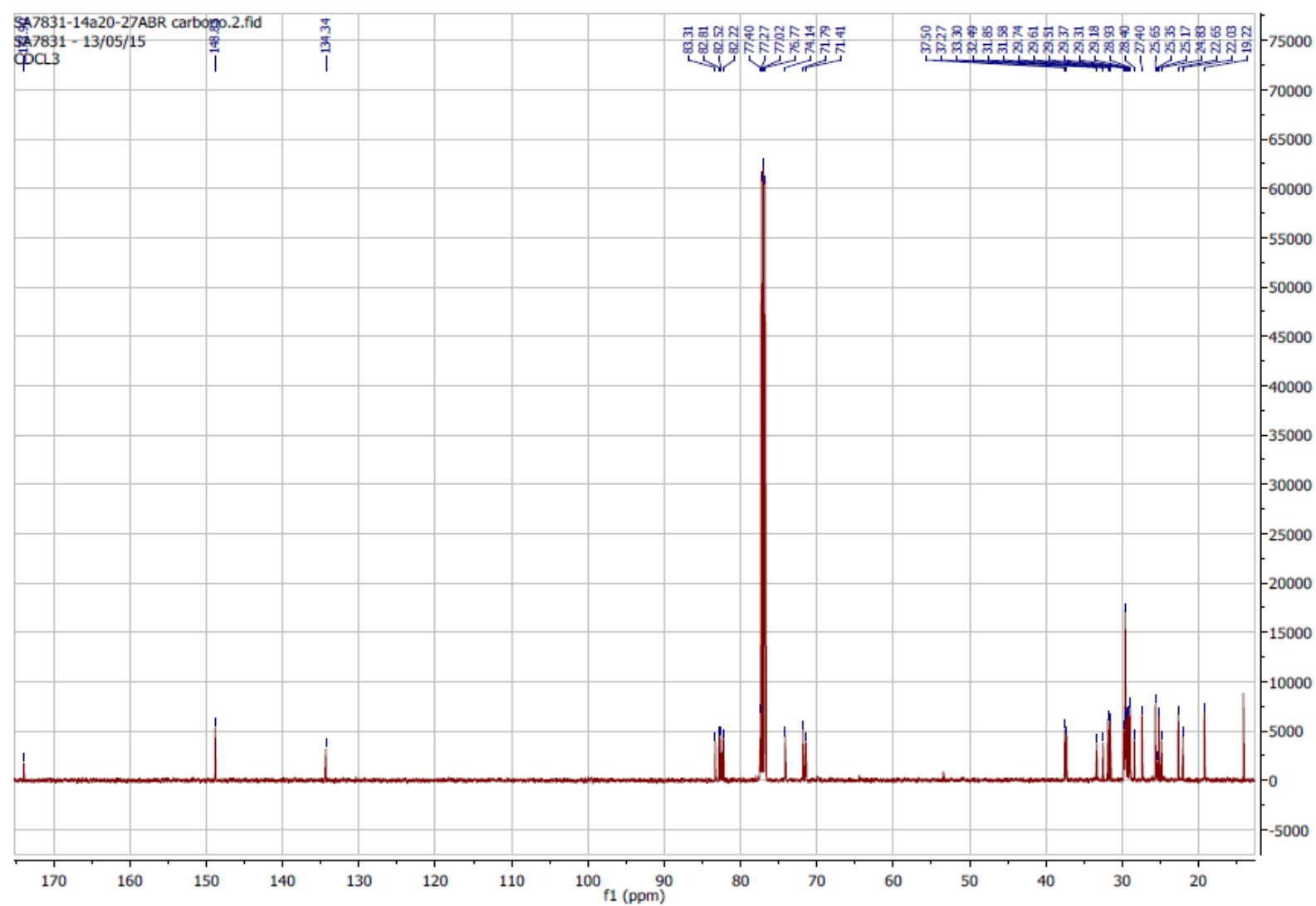

Figure S4. ${ }^{13} \mathrm{C}$ NMR spectrum $\left(500 \mathrm{MHz}, \mathrm{CDCl}_{3}\right)$ of compound 2. 


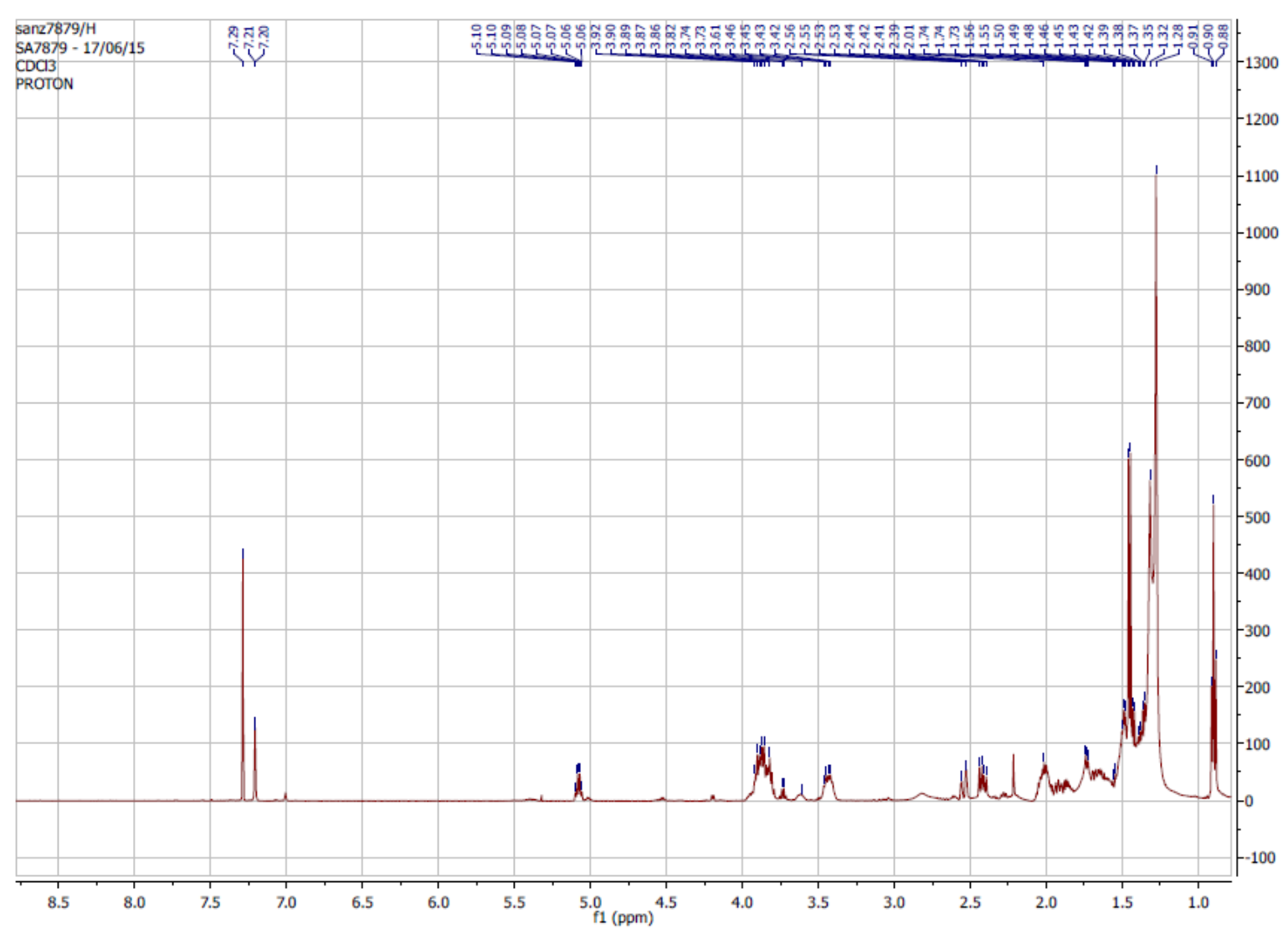

Figure S5. ${ }^{1} \mathrm{H}$ NMR spectrum $\left(300 \mathrm{MHz}, \mathrm{CDCl}_{3}\right)$ of compound 3 .

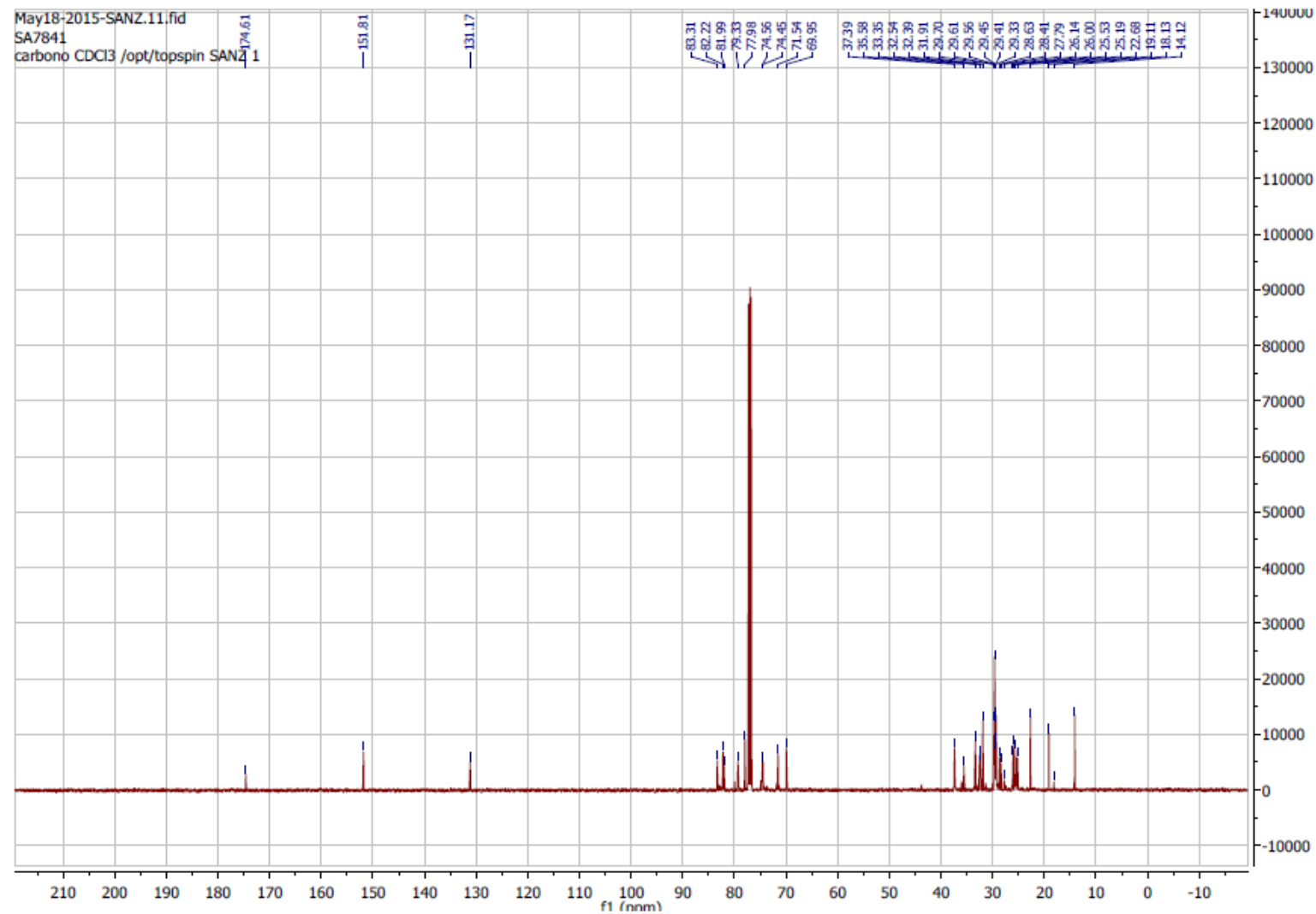

Figure S6. ${ }^{13} \mathrm{C}$ NMR spectrum $\left(500 \mathrm{MHz}, \mathrm{CDCl}_{3}\right)$ of compound 3 . 


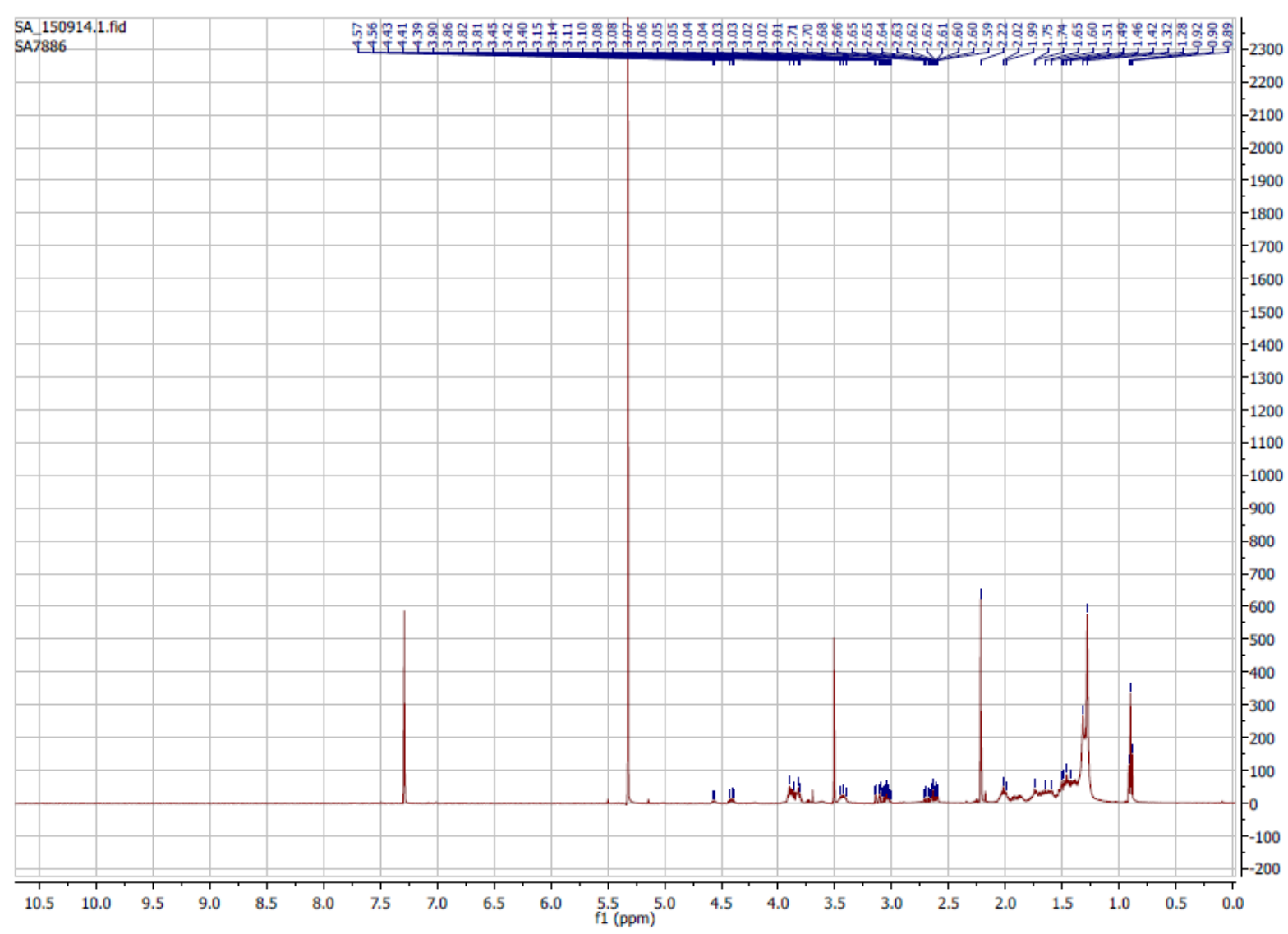

Figure S7. ${ }^{1} \mathrm{H}$ NMR spectrum $\left(300 \mathrm{MHz}, \mathrm{CDCl}_{3}\right)$ of compound 4.

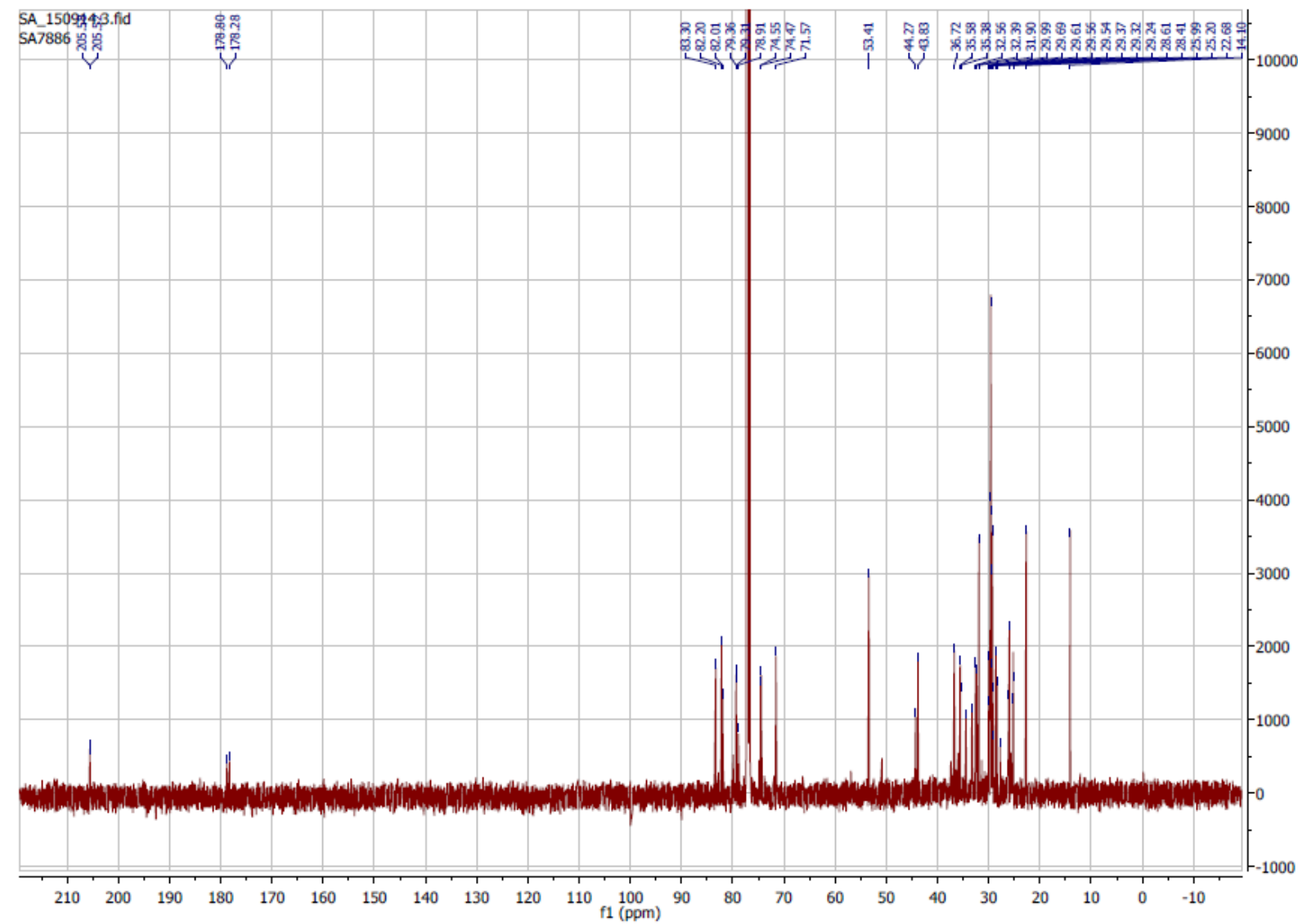

Figure S8. ${ }^{13} \mathrm{C}$ NMR spectrum $\left(500 \mathrm{MHz}, \mathrm{CDCl}_{3}\right)$ of compound 4 . 


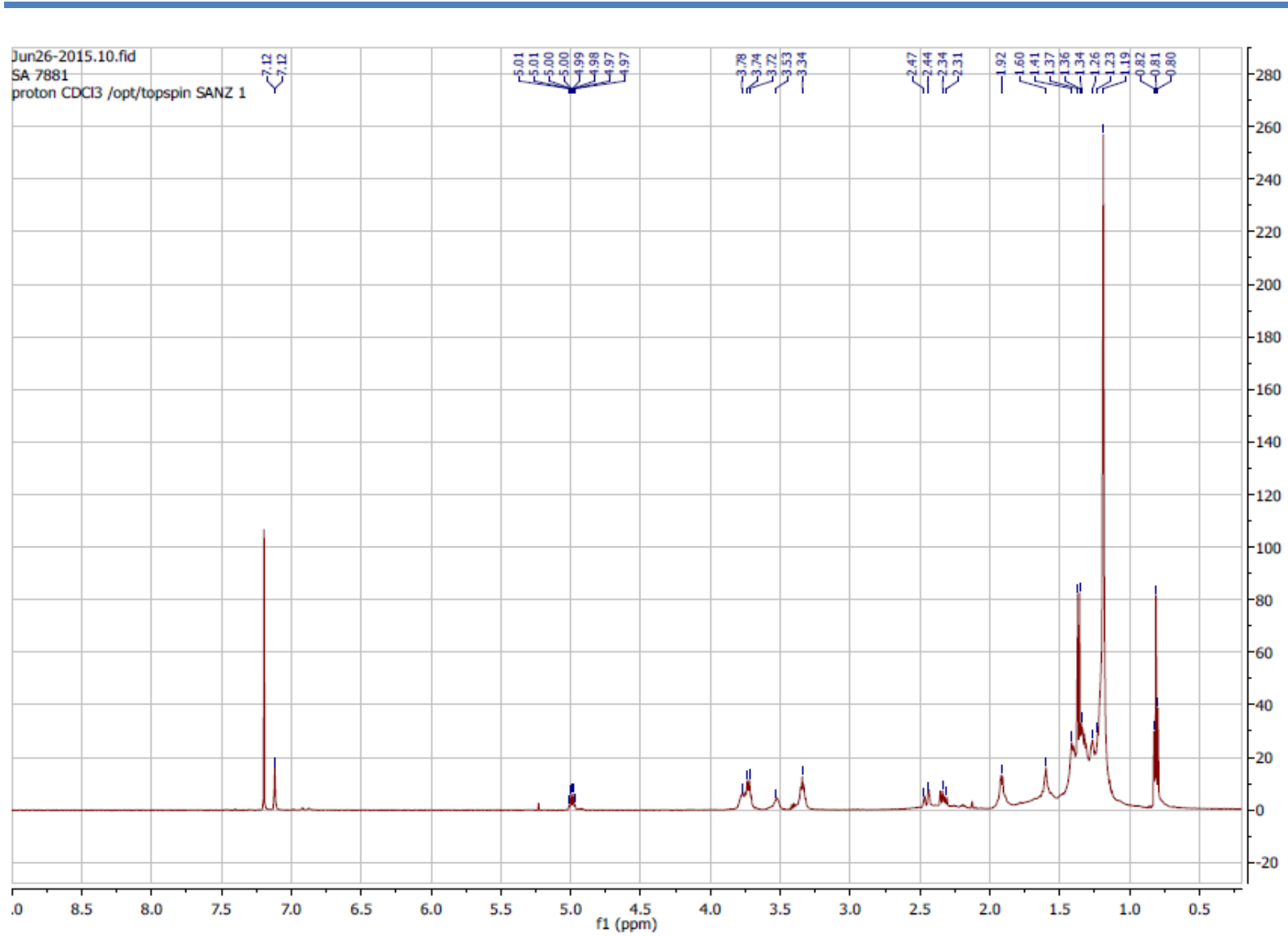

Figure S9. ${ }^{1} \mathrm{H}$ NMR spectrum $\left(300 \mathrm{MHz}, \mathrm{CDCl}_{3}\right)$ of compound 5.

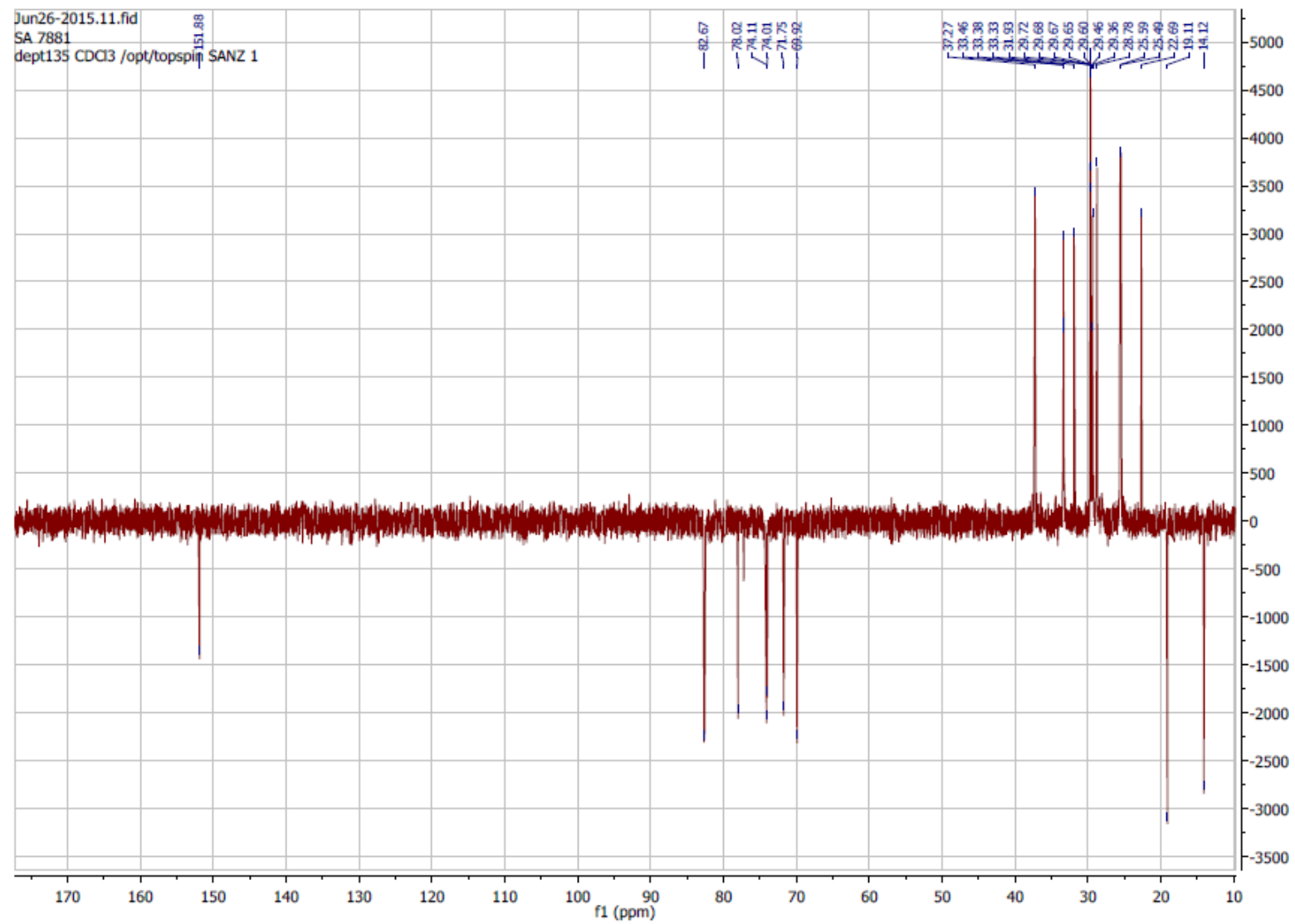

Figure S10. DEPT-135 spectrum $\left(500 \mathrm{MHz}, \mathrm{CDCl}_{3}\right)$ of compound $\mathbf{5}$. 


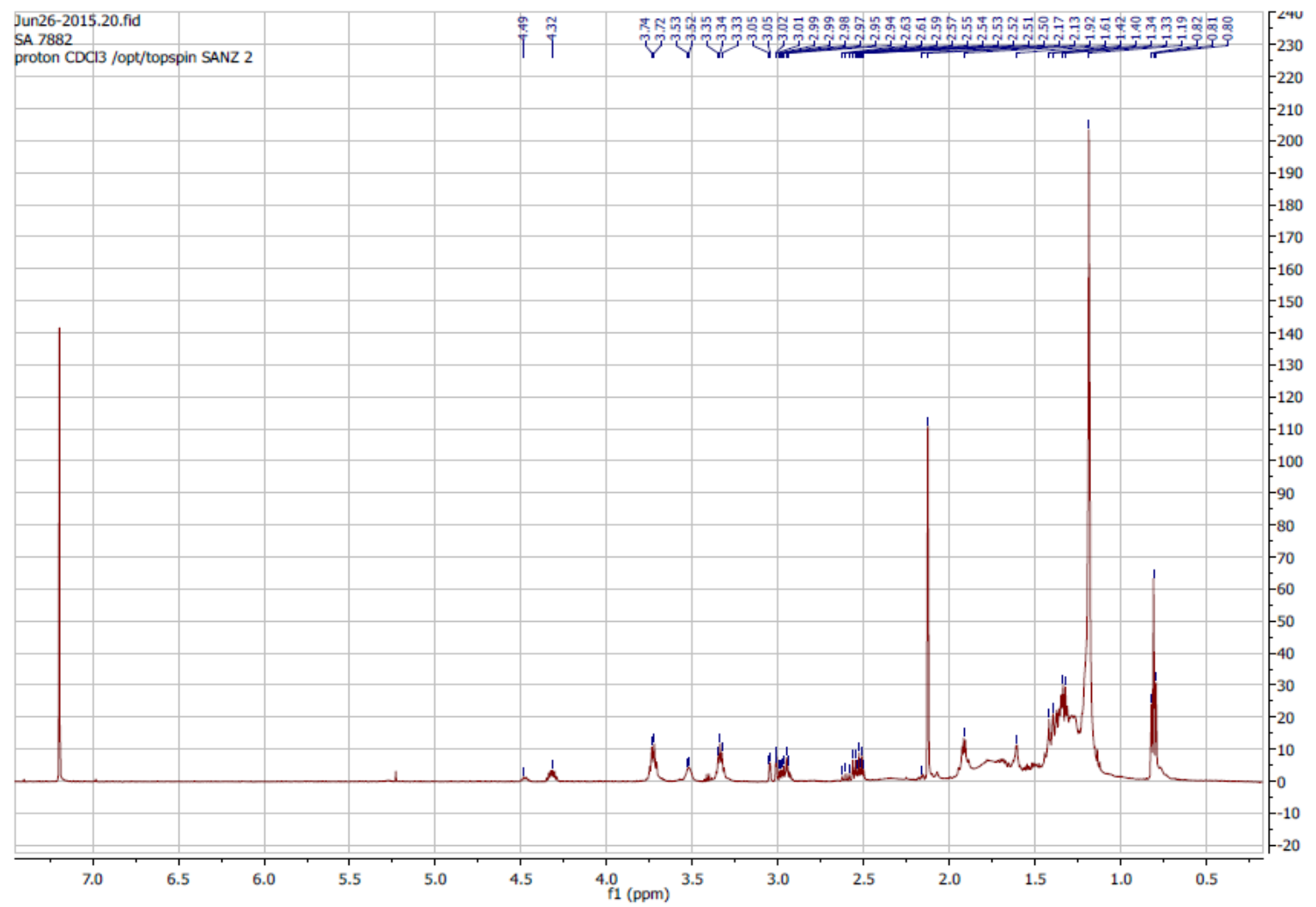

Figure S11. ${ }^{1} \mathrm{H}$ NMR spectrum $\left(300 \mathrm{MHz}, \mathrm{CDCl}_{3}\right)$ of compound 6 .

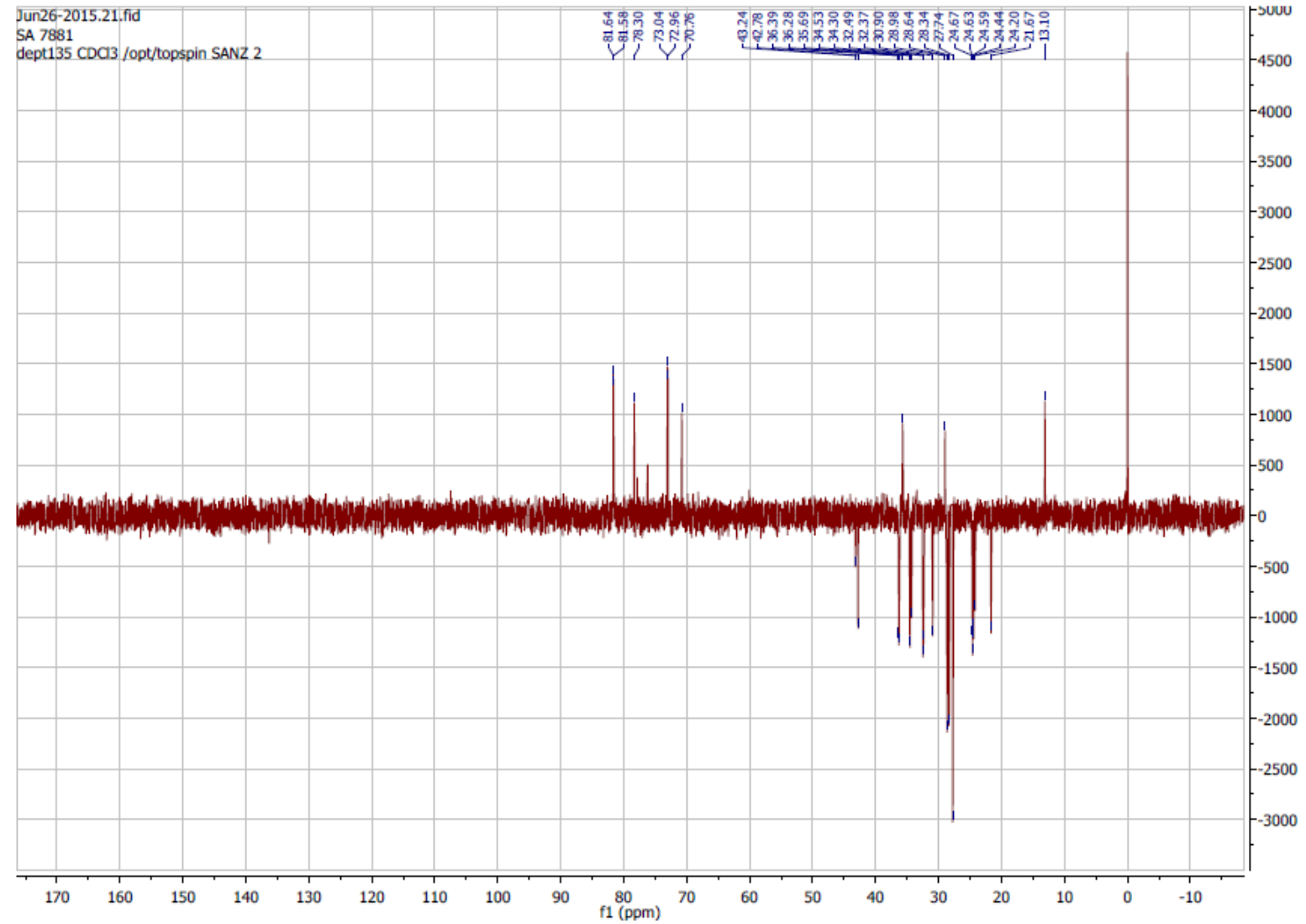

Figure S12. DEPT-135 spectrum $\left(500 \mathrm{MHz}, \mathrm{CDCl}_{3}\right)$ of compound 6. 